\title{
PARTISIPASI PEREMPUAN TANI DALAM USAHATANI STROBERI DI DESA SANTONG KABUPATEN LOMBOK UTARA
}

\section{THE PARTICIPATION OF WOMEN FARMERS IN THE FARMING OF STRAWBERRIES IN SANTONG VILLAGE NORTH LOMBOK REGENCY}

Agus Purbathin Hadi, Hayati, Iqbal Syarif

Fakultas Pertanian Universitas Mataram

\begin{abstract}
ABSTRAK
Penelitian ini bertujuan untuk: 1) Untuk mengetahui partisipasi perempuan tani dalam usahtani stroberi di Desa Santong Kabupaten Lombok Utara, 2) Untuk mengetahui Faktor-Faktor yang Memiliki Hubungan dengan Tingkat Partisipasi dalam Usahatani Stroberi di Desa Santong Kabupaten Lombok Utara. Hasil penelitian menunjukan bahwa tingkat partisipasi perempuan tani dalam usahatani stroberi di Desa Santong Kabupaten Lombok Utara termasik dalam kategori sedang dengan 27 dari 49 responden mendapatkan nilai interval skor 2028. Dalam partisipasi ini terdiri dari tahap perencanaan dan tahap pelaksanaan dimana tahap perencanaan terdiri dari 4 kegiatatan yaitu menentukan jenis tanaman yang akan ditanam, pemanfaatan modal, menentukan jumlah tanaman yang ditanam dan pembagian kerja sedangkan pada tahap pelaksanaan ada 8 kegiatan diantaranya pembuatan media tanam, pembibitan, penanaman, penyiraman, penyulaman, pemupukan,pemangkasan, panen. Rendahnya partisipasi perempuan tani dalam tahap perencanaan disebabkan budaya masyarakat daerah santong yang masih mengharuskan perempuan harus lebih banyak berada di rumah untuk mengurus pekerjaan seperti memasak, bersih,bersih dan mengurus anak sedangkan pada tahap perencanaan pada pembinaan yang dilakukan dengan cara pendekatan kelompok tani dimana dominan dihdiri oleh laki-laki sehingga laki-laki lebih dominan dalam tahap perencanaan dan kegiatan pelaksanaan yang mudah dilakukan seperti penyiraman dan panen dilakukan dominan oleh perempuan yang lebih sering dirumah menguerus tanaman di lahan pekarangan. Menurut hasil uji spearman tidak terdapat faktor-faktor yang memiliki hubungan dengan partisipasi perempuan tani dalam usahatani stroberi di Desa Santong karena semua faktor memiliki nilai signifikan lebih dari 0,05.
\end{abstract}

Kata kunci: Partisipasi, Perempuan Tani, Usahatani Stroberi

\section{ABSTRACT}

This research aims to: 1) to find out the participation of women farmers in usahtani Village in strawberry Santong north Lombok Regency, 2) to find out the factors that have a relationship with the level of participation in the Farming of strawberries in North Lombok Regency Santong Village. Research results show that the level of participation of women farmers in the farming of strawberries in North Lombok Regency Santong Village termasik in the category are with 27 of the 49 respondents to get the value of the interval score 20-28. In this participation consists of the planning and implementation stage stage where the planning phase consists of 4 kegiatatan IE determine what kind of plants will be planted, capital utilization, determine the number of plants grown and the Division of labor whereas at this stage of the implementation of the activities of which there are 8 media-making plant, seedling, planting, watering, fertilizing, trimming, stitching is, harvest. The low participation of women farmers in the planning stages due to popular culture area santong that still requires a lot more women should be at home to take care of jobs such as Cook, clean, clean and take care of the child While in the planning stages in the construction of the approaches made by farmer groups where.

Keywords: participation, women farmers, Farming of strawberries 


\section{PENDAHULUAN}

Sistem dan usaha agribisnis merupakan salah satu ujung tombak kebangkitan perekonomian di Indonesia yang belum pulih dari krisis. Menurut Saragih (2003), agribisnis akan tampil menjadi tulang punggung pembangunan ekonomi nasional. Agribisnis mampu mengakomodasikan tuntutan agar perekonomian nasional terus bertumbuh dan sekaligus memenuhi prinsip kerakyatan, keberlanjutan dan pemerataan baik antar individu maupun antar daerah. Atas dasar pemikiran tersebut maka pembangunan sistem dan usaha agribisnis dipandang sebagai bentuk pendekatan yang paling tepat bagi pembangunan ekonomi Indonesia. Salah satu agribisnis yang memiliki prospek yang cerah adalah agribisnis hortikultura.

Stroberi merupakan salah satu jenis buah-buahan yang memiliki nilai ekonomis yang tinggi. Beberapa petani, khususnya didaerah dataran tinggi telah melakukan budidaya stroberi secara komersial. Prospek usaha stroberi sangat menjanjikan. Stroberi sering ditemukan di pasar swalayan serta supermarket-supermarket ialah stroberi jenis Hibrida yang dihasilkan dari persilangan Fragaria virgiana L var Duchesne asal Amerika dengan Fragali choiloensi $L$ asal Chili (Senewe, 2017).

Menurut Gunawan (2006) Permintaan stroberi di Indonesia bisa dikatakan cukup tinggi karena buah stroberi mempunyai peluang pasar yang semakin luas, buah stroberi ini tidak hanya dapat dikonsumsi langsung tetapi stroberi juga dapat diolah menjadi sirup, selai, dodol, manisan, jus, bahan baku pembantu pembuat es krim dan kue, serta berguna bagi kesehatan.

Wuner (2015) menyatakan bahwa partisipasi tenaga kerja perempuan dalam usahatani stroberi ini petani stroberi menyewa tenaga kerja dari luar keluarga yaitu sebanyak 1 orang tenaga kerja pria untuk persiapan lahan, dengan jumlah hari kerja sebanyak 3 hari dan memberikan upah sebesar Rp.100.000. untuk penanaman petani menyewa tenaga kerja perempuan sebanyak 1 orang dengan jumlah hari kerja 1 hari, dengan upah yang diberikan sebesar Rp.60.000, untuk pemupukan dan penegendalian hama petani menyewa tenaga kerja pria dengan upah Rp.100.000 dan untuk panen petani menggunakan tenaga kerja perempuan sebanyak 1 orang dengan jumlah hari kerja 4 hari dalam 2 minggu, dengan upah yang diberikan sebanyak Rp.240.000. upah untuk tenaga kerja berlaku berbeda yaitu upah untuk tenaga kerja pria sebesar Rp.100.000 dan untuk tenaga kerja perempuan sebesar Rp.60.000.

Desa Santong, Kecamatan Kayangan, Kabupaten Lombok Utara, memiliki potensi alam yang cocok untuk pengembangan tanaman hortikultura dataran medium. Desa Santong merupakan kawasan ekowisata yang dapat membuka peluang pengembangan dalam berbagai usaha ekonomi kreatif baru yang dapat meningkatkan daya tarik ekowisata Desa Santong serta pendapatan masyarakat di Desa Santong, Kecamatan Lombok Utara. Salah satu usaha yang sangat potensial adalah agrowisata dan wisata edukasi berbasis komoditas stroberi yang meliputi pengenalan tanaman dan teknologi budidaya, panen sendiri, gerai penjualan stroberi segar serta olahannya.

Pada akhir tahun 2016, Lembaga Sumberdaya Pembangunan Berkelanjutan (LSPB) bersama Dinas Pertanian Kabupaten Lombok Utara mengintroduksi teknologi budidaya dan pembibitan stroberi pada kelompok-kelompok tani. Dalam usahatani tanaman stroberi di Desa Santong pada kelompok tani tersebut bukan hanya pria yang melakukan kegiatan usahatani namun perempuan juga berpartisipasi dalam kegiatan usahatani tersebut. Untuk partisipasi pria pada komoditas stroberi hanya pada tahap persiapan media tanam seluruhnya dikerjakan oleh tenaga kerja pria. Partisipasi perempuan dalam usahatani khususnya pada komoditas stroberi antara lain pada proses penanaman, pemeliharaan dan pemanenan.

Pengembangan usaha budidaya stroberi dengan cara memanfaatkan lahan pekarangan dalam penanaman tanaman stroberi akan menjadi salah satu peluang usaha baru yang akan meningkatkan daya tarik wisata alam air terjun Sekeper dan Tiu Teja menuju berkembangnya agrowisata petik stroberi sebagai usaha ekonomi produktif baru di Desa Santong Kecamatan Kayangan Kabupaten Lombok Utara (Hadi, 2017).

\section{METODOLOGI PENELITIAN}

Unit analisis dalam penelitian ini yaitu Perempuan Tani Stroberi di Desa Santong Kabupaten Lombok Utara.. Untuk lokasi penelitian ditetapkan secara Purposive Sampling. Lokasi penelitian yang dipilih adalah Desa Santong dengan pertimbangan Desa Santong merupakan salah satu daerah yang menanam stroberi di lahan pekarangan. Sampel yang digunakan adalah kelompok tani yang berada di Desa Santong. Kelompok tani sampel ditentukan secara sensus sebanyak 5 kelompok tani yang mengusahakan stroberi. Analisis yang digunakan adalah Metode Skoring untuk untuk setiap pertanyaan diberikan skor 3 menjadi skor maksimum dan 1 menjadi skor minimum. Dimana skor 3 memiliki arti tinggi, skor 2 memiliki arti sedang dan skor 1 memiliki arti rendah. Analisis selanjutnya untuk melihat hubungan digunakan analisis uji Spearman. Untuk dasar pengambilan keputusan dalam Uji Korelasi Spearman:

- Jika nilai sig. $<0,05$ maka dapat disimpulkan bahwa terdapat korelasi yang signifikan antara varibel yang dihunbungkan. 
- Sebaliknya, jika nilai sig. >0,05 maka dapat disimpulkan bahwa tidak terdapat korelasi yang signifikan antara yang dihubungkan.

kriteria tingkat hubungan (koefisien korelasi) antar varibel berkisar antara $\pm 0,00$ sampai $\pm 1,00$. Adapun kriteria penafsiraannya adalah:

- 0,00 sampai 0,20 artinya: hampir tidak ada korelasi

- 0,21 sampai 0,40 artinya: korelasi rendah

- 0,41 sampai 0,60 artinya: korelasi sedang

- 0,61 sampai 0,80 artinya: korelasi tinggi

- 0,81 sampai 1,00 artinya: korelasi sangat tinggi

\section{HASIL DAN PEMBAHASAN}

\section{Keragaan Usahatani}

Desa santong merupakan salah satu daerah yang berada di Kabupaten Lombok Utara yang memiliki ketinggian dan suhu yang cocok untuk tanaman stroberi selain itu, Desa Santong juga memiliki destinasi wisata alam (ekowisata) yaitu air terjun Tiu Teja dan air terjun Sekeper yang merupakan air terjun tertinggi di pulau Lombok yang mampu memikat wisatawan sekitar 150 orang per minggunya. Menyadari potensi ekowisata yang ada di Desa Santong masyarakat mulai mengembangkan wisata yang ada. Pengembangan ekowisata tersebut dapat meningkatkan pendapatan masyarakat Desa Santong. Pada Kecamatan Kayangan Kabupaten Lombok Utara ada beberapa kelompok tani yang ada di Desa santong yang juga memulai untuk mengembangkan usahatani stroberi. Dimana pengembangan usahatani stroberi tersebut dimaksudkan untuk membangunn ekowisata khususnya stroberi, sehingga Desa Santong dapat menjadi Desa yang memiliki destinasi wisata Stroberi.

Jumlah petani stroberi di Desa Santong sebanyak 48 orang yang terbagi menjadi 5 kelompok tani yaitu kelompok tani Butuh vitamin (BUVITA), Kelompok Tani Beriuk Maju, Kelompok Tani Bunga Bersemi, Kelompok Tani Bunga Ceria dan Kelompok Tani Pade Girang.

\section{Jenis Stroberi di Desa Santong}

Jenis stroberi yang ada di Desa Santong Kabupaten Lombok Utara ada 4 jenis yaitu antara lain Sweet Charlie, Douglas, Camarosa, dan Early Brite. Untuk setiap jenis stroberi memiliki ciri-ciri tersendiri. Ciri-ciri dari setiap stroberi tersebut diperoleh dari keterangan petani yang ada di Desa Santong. Berikut merupakan ciriciri pada setiap jenis stroberi yang ada di Desa Santong:

a. Sweet Charlie adalah salah satu jenis stroberi yang terdapat di Desa Santong yang memiliki ciri khas buah yang manis dan pada saat buah matang namun bagian ujung buah tetap hijau, daun tidak terlalu lebar.

b. Douglas adalah salah satu jenis stroberi yang terdapat di Desa Santong yang memiliki ciri khas buah besar dengan rasa sedikit asam, daun lebar dan merupakan varietas yang kuat bila dibandingkan dengan 3 varietas lainnya.

c. Camarosa adalah salah satu jenis stroberi yang terdapat di Desa Santong yang memiliki ciri khas buah lonjong berbentuk hati dan memiliki daun yang lebar seperti Douglas.

d. Early Brite adalah salah satu jenis stroberi yang terdapat di Desa Santong yang memiliki ciri khas buah besar seperti memiliki dua buah yang dempet dan memiliki daun yang lebar.

\section{Karakteristik Responden} keluarga.

Karakteristik responden dalam penelitian ini meliputi umur, pendidikan, pekerjaan dan jumlah anggota

Umur Responden. Hasil penelitian menunjukkan bahwa rata-rata umur responden petani stroberi adalah kisaran umur 15-64 tahun. Hal ini berarti dilihat dari segi umur responden berada pada umur produktif, artinya secara fisik responden tersebut mampu melaksanakan suatu aktifitas dengan baik.

Tingkat Pendidikan. Berdasarkan tabel 4.4.2 dapat dilihat tingkat pendidikan responden petani stroberi Tergolong rendah. Dimana untuk tingkat pendidikannya adalah SD pendidikan perempuan tani responden stroberi di Desa santong yang terendah adalah (SD) dan pendidikan tertingginya adalah (S1). Responden pada penelitian ini juga ada yang tidak sekolah dan ada yang tidak menyelesaikan sekolah, oleh sebab itu maka pendidikan responden petani stroberi di Desa Santong memiliki golongan tingkat pendidikan yang rendah.

Pekerjaan Responden. Pekerjaan utama perempuan tani responden tertinggi adalah Ibu Rumah Tangga dan pekerjaan utama perempuan tani responden yang terendah adalah Buruh Tani, Bidan dam Penjahit. pekerjaan sampingan yang paling banyak adalah Petani dan pekerjaan sampingan perempuan tani yang terendah adalah pekerjaan sampingan sebagai Buruh Tani. 
Jumlah Anggota Keluarga. sebagian besar keluarga perempuan tani responden tergolong dalam keluarga menengah. Dimana keluarga menengah terdiri dari tiga sampai empat anggota keluarga didalamnya.

\section{Partisipasi Perempuan Tani dalam Usahatani Stroberi}

Partisipasi perempuan tani dalam usahatani stroberi di Desa Santong termasuk dalam kategori sedang dengan 27 dari 49 responden menyatakan bahwa keikutsertaan perempuan tani dalam usahatani stroberi lebih dominan dilakukan secara bersama-sama dengan laki-laki. Hal ini disebabkan oleh beberapa kegiatan dominan dilakukan oleh laki laki seperti dalam tahap perencanaan diantaranya menentukan tanaman yang akan ditanam dan menentukan jumlah tanaman yang akan ditanam sedangkan perempuan dominan pada tahap pelaksanaan seperti penyiraman dan panen. Selebihnya kegiatan usahatani lainnya dilakukan dominan secara bersama-sama.

Dalam partisipasi ini terdiri dari tahap perencanaan dan tahap pelaksanaan dimana tahap perencanaan terdiri dari 4 kegiatatan yaitu menentukan jenis tanaman yang akan ditanam, pemanfaatan modal, menentukan jumlah tanaman yang ditanam dan pembagian kerja sedangkan pada tahap pelaksanaan ada 8 kegiatan diantaranya pembuatan media tanam, pembibitan, penanaman, penyiraman, penyulaman, pemupukan, pemangkasan, panen.

Rendahnya partisipasi perempuan tani dalam tahap perencanaan disebabkan budaya masyarakat daerah santong yang masih mengharuskan perempuan harus lebih banyak berada di rumah untuk mengurus pekerjaan seperti memasak, bersih,bersih dan mengurus anak sedangkan pada tahap perencanaan pada pembinaan yang dilakukan dengan cara pendekatan kelompok tani dimana dominan dihdiri oleh laki-laki sehingga laki-laki lebih dominan dalam tahap perencanaan dan kegiatan pelaksanaan yang mudah dilakukan seperti penyiraman dan panen dilakukan dominan oleh perempuan yang lebih sering dirumah menguerus tanaman di lahan pekarangan.

\section{Partisipasi Perempuan Tani dalam Tahap Perencanaan pada Usahatani Stroberi}

Partisipasi perempuan tani pada tahap perencanaan tergolong rendah disebabkan pada aspek menentukan jenis stroberi yang akan ditanam, menyediakan modal untuk usahatani stroberi, menentukan jumlah tanaman stroberi yang akan ditanam dan menentukan penempatan kerja dominan dilakukan oleh suami perempuan tani karena yang mengikuti pembinaan usahatani stroberi secara langsung adalah suami perempuan tani sehingga yang lebih mengetahui tentang perencanaan.

Rendahnya partisipasi perempuan tani ini disebabkan pada saat pembentukan kelompok dan pembinaan sebagian besar diikuti oleh laki-laki hal ini karena budaya disana masih mengharuskan perempuan lebih banyak berada di rumah untuk mengurus pekerjaan rumah seperti masak, bersih-bersih dan mengurus anak. Sehingga hal tersebut yang membuat masyarakat khususnya laki-laki mendapatkan pengetahuan lebih dibandingkan dengan perempuan dalam hal pembentukan kelompok dan pembinaan tersebut di Desa Santong. Namun diharapkan laki-laki atau suami yang mengikuti pembinaan dapat memberikan pengetahuan atau informasi yang telah diperoleh dari pembinaan yang sudah diikuti kepada perempuan tani sehingga perempuan tani memiliki pengetahuan yang sama dengan suami mereka yang mengikuti pembinaan.

Namun kenyataannya informasi yang didapatkan oleh suami perempuan tani tidak disampaikan semua ke perempuan tani sehingga kurangnya pengetahuan dalam merencanakan permodalan, jenis stroberi dan jumlah yang akan ditanam mem;pengaruhi tingkat partisipasi perempuan tani yang pada penelitian ini memiliki tingkat partisipasi yang rendah.

Partisipasi Perempuan Tani pada Setiap Bagian Kegiatan-Kegiatan Tahap Perencanaan pada Usahatani Stroberi.

Laki laki lebih dominan berpartisipasi dalam kegiatan perencanaan. Hal ini dapat dilihat pada setiap bagian tahapan, bagian tahapan yang pertama pada tahap perencanaan yaitu menentukan jenis stroberi yang akan ditanam, Kegiatan perencanaan menentukan jenis tanaman stroberi yang akan ditanam merupakan salah satu kegiatan perencanaan dalam usahatani stroberi di desa Santong. penanaman jenis stroberi yang akan ditanam sesuai keputusan dari perempuan tani dan atau suami.

\section{Partisipasi Perempuan Tani dalam Tahap Pelaksanaan pada Usahatani Stroberi.}

Partisipasi perempuan tani dalam usahatani stroberi pada tahap pelaksanaan dapat dilihat dari beberapa aspek diantaranya dalam mempersiapkan media tanam, keikutsertaan perempuan tani dalam pembibitan, keikut sertaan perempuan tani dalam penanaman, keikutsertaan perempuan tani dalam penyiraman, keikutsertaan perempuan tani dalam penyulaman, keikutsertaan permpuan tani dalam pemupukan, keikut sertaan perempuan tani dalam pemangkasan, keikutsertaan perempuan tani dalam pemanenan.

Partisipasi perempuan tani dalam tahap pelaksanaan tergolong sedang karena karena hampir semua aspek dalam pelaksanaan dilakukan secara bersama-sama yaitu perempuan tani bersama suami. Adapun dalam 
beberapa aspek pelaksanaan usahatani stroberi perempuan tani lebih dominan dalam pelaksanaannya seperti aspek pemanenan dan penjualan. 


\section{Partisipasi Perempuan Tani pada Setiap Bagian Kegiatan-Kegiatan Tahap Pelaksanaan Usahatani Stroberi.}

Pada tahap pelaksanaan terdapat 8 bagian yang pertama adalah mempersiapkan media tanam Kegiatan Pembuatan media tanam untuk usahatani stroberi diantaranya membuat rak tempat tanaman stroberi diletakkan dan pengisian tanah pada polibag sebagai media tanam tanaman stroberi. Berdasarkan hasil penelitian yang dominan melakukan adalah laki-laki.

\section{Faktor-Faktor yang Memiliki hubungan dengan Partisipasi Perempuan Tani dalam Usahatani Stroberi}

Faktor-faktor yang memiliki hubungan dengan partisipasi perempuan tani pada usahatani stroberi adalah Umur, Pekerjaan, Pendidikan dan Jumlah Total Tanaman. Beberapa faktor tersebut akan melihat bagaimana partisipasi perempuan tani pada Usahatani stroberi di Desa Santong. Untuk melihat apakah setiap faktor tersebut memiliki hubungan terhadap partisipasi perempuan pada usahatani stroberi di Desa Santong dilihat melalui nilai signifikansi.Jika nilai signifikan $<0,05$ maka dapat disimpulkan bahwa terdapat korelasi yang signifikan antara varibel yang dihunbungkan. Untuk lebih jelas dapat dilihat pada tabel berikut:

Tabel 1. Hasil Analisis Faktor-Faktor Yang Mempengaruhi Partisipasi Perempuan Tani di Desa Santong Kabupaten Lombok Utara, 2018

\begin{tabular}{lll}
\hline No. & Faktor-Faktor & Partisipasi \\
\hline 1 & Umur & 0.999 \\
2 & Pendidikan & 0.422 \\
3 & Pekerjaan & 0.075 \\
4 & Jumlah Tanaman Ditanam & 0.094 \\
\hline
\end{tabular}

Sumber: Data Primer Diolah

Berdasarkan tabel 1. dapat diketahui nilai signifikan untuk faktor umur dalam partisipasi perempuan tani pada usahatani stroberi adalah 0,999 > 0,05 maka dapat disimpulkan bahwa faktor umur tidak memiliki hubungan terhadap tingkat partisipasi perempuan tani dalam usahatani stroberi di Desa Santong yang artinya tinggi rendahnya umur atau tua mudanya responden tidak memiliki hubungan terhadap tingkat partisipasinya. Hal itu tidak sejalan dengan hasil penelitian Aji yang berjudul partisipasi wanita tani dalam kegiatan percepatan penganekaragaman konsumsi pangan (P2KP) melalui program kawasan rumah pangan lestari (KRPL) di Kabupaten Purworejo yang menyatakan bahwa faktor umur memiliki pengaruh terhadap tingkat partisipasi wanita tani.

nilai signifikan untuk faktor pendidikan dalam partisipasi perempuan tani pada usahatani stroberi adalah 0,422 > 0,05 maka dapat disimpulkan bahwa faktor pendidikan tidak memiliki hubungan terhadap tingkat partisipasi perempuan tani dalam usahatani stroberi di Desa Santong yang artinya semakin tinggi tingkat pendidikan responden tidak memiliki pengaruh terhadap tingkat partisipasinya dalam tahap perencaan usahatani stroberi. Hal itu tidak sejalan dengan hasil penelitian penelitian Aji yang berjudul partisipasi wanita tani dalam kegiatan percepatan penganekaragaman konsumsi pangan (P2KP) melalui program kawasan rumah pangan lestari (KRPL) di Kabupaten Purworejo yang menyatakan bahwa faktor pendidikan memiliki hubungan terhadap tingkat partisipasi wanita tani.

nilai signifikan untuk faktor pekerjaan dalam partisipasi perempuan tani pada usahatani stroberi adalah 0,075> 0,05 maka dapat disimpulkan bahwa faktor pekerjaan tidak memiliki hubungan terhadap tingkat partisipasi perempuan tani dalam usahatani stroberi di Desa Santong yang artinya keberagaman pekerjaan responden tidak memiliki pengaruh terhadap tingkat partisipasinya dalam tahap perencaan usahatani stroberi. Hal itu tidak sejalan dengan hasil penelitian Yulida yang berjudul faktor-faktor pembentuk partisipasi petani terhadap program sistem pertanian terpadu pt. rapp di Kabupaten Pelalawan yang menyatakan bahwa faktor pekerjaan memiliki hubungan terhadap tingkat partisipasi wanita tani.

nilai signifikan untuk faktor jumlah tanaman yang ditanam dalam partisipasi perempuan tani pada usahatani stroberi adalah 0,094>0,05 maka dapat disimpulkan faktor jumlah total tanaman tidak memiliki hubunganterhadap tingkat partisipasi perempuan tani dalam usahatani stroberi di Desa Santong yang artinya semakin semakin banyak tanaman yang ditanam responden tidak memiliki hubungan terhadap tingkat partisipasinya dalam tahap perencaan usahatani stroberi. 


\section{KESIMPULAN DAN SARAN}

\section{Kesimpulan}

Kesimpulan yang dapat diambil pada penelitian ini adalah: 1) partisipasi perempuan tani dalam usahatani stroberi di Desa Santong termasuk dalam kategori sedang dengan 27 dari 49 responden menyatakan bahwa partisipasi perempuan tani dalam usahatani stroberi dominan dilakukan secara bersama-sama. 2) Dari hasil penelitian ini didapatkan kesimpulan tidak terdapat faktor-faktor yang memiliki hubungan dengan partisipasi perempuan tani dalam usahatani stroberi di Desa Santong karena semua faktor memiliki nilai signifikan lebih dari 0,05

Saran

Setelah melakukan penelitian terhadap Kelompok Wanita Tani di Kecamatan Selaparang maka diajukan beberapa saran sebagai berikut: 1) Untuk perempuan tani stroberi agar meningkatkan partisipasinya dalam usahatani stroberi untuk mewujudkan desa santong sebagai kampung stroberi, 2) Untuk pemerintah agar memberikan bantuan bibit kepada petani stroberi di Desa Santong dengan tujuan mengembalikan semangat petani dalam mengusahakan tanaman stroberi pasca gempa. 3) Untuk pemerintah ataupun instasi yang terkait dalam pembinaan kedepannya juga diharapkan melibatkan perempuan sehingga dapat meningkatkan tingkat partisipasinya.

\section{DAFTAR PUSTAKA}

Gunawan, 2006., Usahatani Stroberi Lokal. Penerbit Armico. Bandung

Hadi A, P. 2017.penguatan kelembagaan kelompok tani dalam mendukung pengembangan desa santong menjadi desa agrowisata stroberi di kabupaten lombok utara. Laporan Akhir Program Pengabdian Masyarakat. Unram

Saragih B. 2001. Pembangunan Sistem Agrobisnis di Indonesia dan Peran Public Relation. Jurnal Sosial Ekonomi Pertanian dan Agrobisnis Volume 1 No. 3. 149-226. Fakultas Pertanian Universitas Udayana.

Senewe. 2017.Faktor Penunjang Dan Penghambat Usahatani Stroberi Di Kelurahan Rurukan Dan Rurukan Satu,Kecamatan Tomohon Timur, Kota Tomohon. Jurnal. gri-SosioEkonomiUnsrat,ISSN 19074298, Volume12Nomor1A,

Wuner, Mikhaael Becky. 2015. Kajian Usahatani Stroberi Di Kelurahan Rurukan Kecamatan Tomohon Timur Kota Tomohon. Jurnal. Fakultas Pertanian. UNIVERSITAS SAM RATULANGI. MANADO. 